\title{
ジムボールを用いたストレッチング運動がヒラメ筋の H波に及ぼす影響
}

\author{
Influence of a Spinal Mobilization Exercise Using a Gym Ball on the Soleus H-Reflex
}

\author{
江口 淳子1） 小原 謙一2) 渡邊 進2) 石田 弘 2 (2) \\ Atsuko EGUCHI ${ }^{1)}$, KenICHI KOBARA ${ }^{2)}$, Susumu WATANABE ${ }^{2)}$, Hiroshi ISHIDA ${ }^{2)}$ \\ 1) Department of Physical Therapy, Fukuoka Rehabilitation College: 3-29-17 Hakata-Ekimae, Hakata-ku, Fukuoka city, Fukuoka \\ 812-0011, Japan. TEL +81 92-475-1000 FAX +81 92-475-1002 \\ 2) Department of Rehabilitation, Faculty of Health Science and Technology, Kawasaki University of Medical Welfare
}

Rigakuryoho Kagaku 25(2): 281-284, 2010. Submitted Oct. 1, 2009. Accepted Nov. 11, 2009.

ABSTRACT: [Purpose] The purpose of this study was to investigate the influence of stretching exercise on the excitability of the soleus muscle using a gym ball. [Subjects] Ten healthy males aged $24.7 \pm 3.9$ years without pathologies in the leg and/or trunk participated in this study. [Methods] Excitability of the soleus muscle was measured indirectly using the H-reflex. In a control test, the subjects rested in the supine position for a minute. In the exercise test, the same subjects were asked to practice the stretching exercise for a minute. The soleus H-reflex amplitude was measured before and after rest or exercise in the supine position. The H-reflex amplitude before and after was compared under each condition. [Results] In the exercise test, the H-reflex after exercise was significantly lower than the H-reflex before exercise, while in the control test, there was no significant difference between the H-reflex before and after rest. [Conclusion] The result shows that the stretching exercise using the gym ball controlled the excitability of the soleus muscle.

Key words: gym ball, stretching exercise, H-reflex

要旨：〔目的〕本研究の目的はジムボールを用いたストレッチング運動がヒラメ筋の興奮性に及ぼす影響を評価す ることであった。〔対象〕下肢・体幹に疾患のない平均年齢 $24.7 \pm 3.9$ 歳の健常男性 10 名であった。〔方法〕ヒラメ

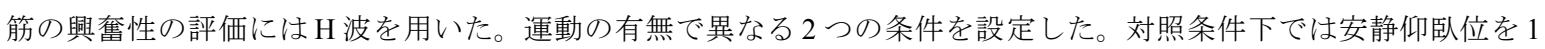
分間とらせた。運動条件下では同じ被験者にジムボールを用いたストレッチング運動を1分間行わせた。各条件を 施行する前後のヒラメ筋 $\mathrm{H}$ 波を計測し, 各条件で前後の $\mathrm{H}$ 波を比較した。〔結果〕運動条件下では運動前に比べ運 動後で $\mathrm{H}$ 波振幅は有意に小さい值を示した。一方安静条件下では，前後に有意差はなかった。〔結語〕ボールを用 いたストレッチング運動を行うことで，ヒラメ筋のH波の振幅は小さくなり，ヒラメ筋の興奮性は抑制されたと考 える。

キーワード : ジムボール, ストレッチング運動, H波

1) 福岡リハビリテーション専門学校＼cjkstart理学療法学科：福岡県福岡市博多区博多駅前3-29-17 ( T812-0011) TEL 092-475-1000

2) 川崎医療福祉大学 医療技術学部リハビリテーション学科

受付日 2009年10月1日 受理日 2009年11月11日 


\section{I. はじめに}

身体の柔軟性は，動作のパフォーマンス向上や，障 害を予防するうえで重要な要素の一つであり，スポー ツや理学療法において, 準備段階として静的ストレッ チングを用いることは多い1)。たとえば, スポーツの分 野ではハムストリングスの肉離れは代表的なスポーツ 障害の一つであるが，その予防，あるいは再発予防の 手段としてストレッチングは非常に重要な役割を果た している2)。また, 心身ともに健康で過ごせることを目 標としたヘルスプロモーションが盛んに行われている 現在, 高齢者に対する転倒や寝たきり予防のための運 動として，あるいは，長時間同じ姿勢をとり続けるデ スクワーカーなど労働者に対しての肩こりや腰痛改善 の運動として, 様々なメディアで健康体操の一つとし てストレッチングは紹介されている。なかでも, 最近 ではジムボールを使ったストレッチング運動が多く紹 介されており，バランス強化と柔軟性向上という，筋 の伸長のみならずプラスアルファの効果が期待される3) として，様々な場面で頻繁に用いられている。このジ ムボールを用いたストレッチング運動の一つに背筋群 をストレッチする運動が紹介されている。筆者らは先 行研究4,5)にて, 健常成人男性を対象にこのジムボール を用いたストレッチング運動を行い, 脊柱可動性に対 する効果を脊柱計測分析器（インデックス社製 Spinal Mouse $\left.{ }^{\circledR}\right)$ を用いて検討した。その結果，胸・腰椎の彎 曲角に変化は見られなかったが, 仙骨後面が鉛直線に 対して作る仙骨傾斜角, 寸なわち骨盤傾斜角がストレッ チング運動後に有意に増大していた。骨盤の傾斜に直 接影響を及ぼすハムストリングスは，上述の運動にお いては直接的には伸長されていない。このことから, ジムボールを用いたストレッチング運動によって脊柱 周辺の筋の支配神経の興奮性が抑制され, 脊髄からの 影響により他の髄節神経にて支配されているハムスト リングスの興奮性も抑制されたと考え, ジムボールを 用いたストレッチングのプラスアルファの効果である と考えた。しかしながらこのことについては検証して いないため推測の域を出ない。

そこで本研究にて, ジムボールによるハムストリン グスの興奮性の抑制について，H波を用いることで検 証することを考えたが， $\mathrm{H}$ 波をハムストリングスから 導出するのは困難である。そこで春柱起立筋とは別髄 節であり, 八ムストリングスのうちの半腱様筋, 半膜 様筋, 大腿二頭筋長頭と同様に脛骨神経によって支配 されているヒラメ筇の $\mathrm{H}$ 波を測定し, その振幅を運動
前後で比較することで,「ジムボールを用いたストレッ チング運動が脛骨神経を介してその被支配筋群の興奮 性を抑制する」という推察を検証することを目的とした。

\section{II. 対象と方法}

\section{1. 対象}

対象は，下肢・体幹に疾患の無い健常男性 10 名（平 均年齢 : $24.7 \pm 3.9$ 歳, 身長 : $176.7 \pm 6.1 \mathrm{~cm}$, 体重 : 71.3 $\pm 8.9 \mathrm{~kg})$ とした。全対象者には事前に本研究の趣旨と 目的を文書にて説明した上で協力を求め，同意書に署 名・捺印を得た。

2. 方法

ヒラメ筋 $\mathrm{H}$ 波の導出には, 刺激装置 (Neuropack 8, 日 本光電社製）を用いて右膝窩部から経皮的に脛骨神経 を電気刺激した。皮膚の接触抵抗を下げる為に皮膚前 処理剂を使用して前処理を施した右ヒラメ筋の筋腹部 の皮膚に表面電極を貼付して $\mathrm{H}$ 波を導出し, 筋電計 (Neuropack 8, 日本光電社製) に記録した。

刺激は持続 $1 \mathrm{msec} の$ 矩形波で, 刺激頻度は $1 \mathrm{~Hz}$ とし た。刺激強度は村岡らの方法6)に従い, 安静仰臥位の 状態で最大 $\mathrm{M}$ 波振幅の $20 \sim 40 \%$ の $\mathrm{H}$ 波が得られる強度 とした。誘発刺激を繰り返し施行し, 安定した 4 回目以 降で, 8 回分の $\mathrm{H}$ 波を採用した。H波は振幅值を計測し, 採用された 8 回の計測值の平均を求めた。

ジムボールを用いたストレッチング運動は, 筆者ら の先行研究 4,5$)$ に従い, 肩・时・股・膝関節を軽度屈曲 位, 前腕と下腿を軽く接地させ, 頭部は軽く垂らせた リラックスした状態でボール上に腹這位を 1 分間とら せた。その際の膝関節は45 度屈曲位とし, ボールの頂 点は臍のレベルに合わせるように指示した。なお, ボー ルは最大直径 $65 \mathrm{~cm}$ (Reebok 社製 Gym ball）のものを使 用した。ボールの硬さは $10 \mathrm{~kg}$ の重錘をボールの頂点に のせた際にボールの鉛直方向の直径が $7 \mathrm{~cm}$ 縮む程度と し, 空気の量を調節した。運動時間については, 筆者 らの先行研究 ${ }^{5)} に て, 1$ 分閒行うことで脊柱可動性の増 大が確実に認められたため, 本研究でも 1 分間とした。

実験条件は，ストレッチング運動を行う条件（運動 条件) と運動を行わない条件 (安静条件) の2条件とし た。運動条件では，ストレッチング運動を行う前後の $\mathrm{H}$ 波を仰臥位にて記録した。また, 安静条件ではス卜 レッチング運動の代わりに安静仰臥位を1分間とらせ, その前後の $\mathrm{H}$ 波を仰臥位にて記録した。対象者には 24 時間以上空けて2条件をランダムな順序で施行した。各 
表1 各条件での運動前後のヒラメ筋H波の 平均值と標準偏差

\begin{tabular}{|c|c|c|}
\hline & 運動条件 & 安静条件 \\
\hline 運動前 & $6.5 \pm 2.37$ & $5.3 \pm 2.5$ \\
\hline 運動後 & $5.1 \pm 2.2]^{*}$ & $5.2 \pm 2.3]^{\text {n.s. }}$ \\
\hline
\end{tabular}

mean \pm S.D. $[\mathrm{mA}]$

$*$ : $\mathrm{p}<0.05$, n.s.: not significant

条件において, 運動あるいは安静前後で $\mathrm{H}$ 波の実測值 (mV) を比較した。

統計解析用ソフトウェアはSPSS for Windows Ver. 15.0 $\mathrm{J}$ (エス・ピー・エス・エス社製)を用いた。運動前後 の $\mathrm{H}$ 波振幅を比較するための統計学的解析には対応の あるt-testを用い, 有意水準を $5 \%$ 未満とした。

\section{III. 結 果}

各条件における運動前後の $\mathrm{H}$ 波振幅を表 1 に示す。 運動条件では, 運動前の平均 $\mathrm{H}$ 波振幅は $6.5 \pm 2.3 \mathrm{~mA}$, 運動後は $5.1 \pm 2.2 \mathrm{~mA}$ で, 運動後は有意に小さい值を示 した（ $\mathrm{t}=6.05$, 自由度 $9, \mathrm{p}<0.01)$ 。安静条件では運動前 $5.3 \pm 2.5 \mathrm{~mA}$, 運動後は5.2 $\pm 2.3 \mathrm{~mA}$ であり, 有意差は認 められなかった（ $\mathrm{t}=1.14$, 自由度 $9, \mathrm{p}=0.28)$ 。このこと から, ジムボールを用いたストレッチ運動は, 脛骨神 経を介してヒラメ筋の興奮性を抑制し得ることが示唆 された。

\section{IV. 考 察}

本研究結果では, ボールを用いたストレッチング運 動を行うことで, 脛骨神経に支配されているヒラメ筋 の $\mathrm{H}$ 波振幅は運動前に比べ有意に小さくなった。すな わち脛骨神経を介してその被支配筋群の一つである七 ラメ筋の興奮性が抑制されたと考える。

ボールは支えるという機能的特性をもつ。これは空 気圧の反発力とクッション作用が互いに補うように作 用することで，ボールに触れている体の部分に馿染ん だ形で，ソフトに体の動きを支えることができること による。この特性は, リラクセーションにも役立って おり，ボールを抱くように静かに体を預ける姿勢は筋 の弛緩を進め, また腕や脚を脱力させてボールに預け る姿勢はリラックスした状況をつくることができると 言われている7)。本研究においても, 全身リラックスし た状態で, 頭部, 下肢の質量によって脊柱が頭部, 尾
部方向へ毫引されやすい状態となり, 脊柱周辺にある 脊柱起立筋や多裂筋が適度に牽引, 伸長されたものと 思われる。筋伸長による生理的作用には, 脊髄神経機 構を刺激して生じる伸張反射, 自己抑制, 拮抗作用, 反 回作用などが挙げられているが 8,9 , その中でも一定時 間以上筋が伸長されることによって起こる自己抑制の 作用により背筋群の支配神経の興奮性が抑制されたの ではないかと考える。

さらに，脛骨神経を介したヒラメ筋の興奮性の抑制 効果については, 吉崎ら ${ }^{10)}$ や弓永ら ${ }^{11)}$ の研究から次の ように推察する。吉崎ら ${ }^{10)}$ は下腿三頭筋に対寸る他動 的筋伸長により反対側のヒラメ筋 $\mathrm{H}$ 波に弱い抑制を認 めたと報告している。また弓永ら ${ }^{11)}$ は, 背臥位, 立位 時, 右側下肢荷重肢位という姿勢変化が，上肢筋に対 応する春髄神経機能の興奮性にどのように影響するか について右短母指外転筋より導出した $\mathrm{F}$ 波を用いて検 討した結果，一側下肢荷重肢位で脊髄の興奮性増加を 示したと報告している。これらの研究は, 他動的に伸 長されたあるいは随意的に収縮した筋のみならず，他 の髄節レベルで支配されている筋へも興奮性の促通や 抑制といった影響が及ぶことを示唆している。これら の報告から, 本研究においても背筋群が伸長されたこ とによって神経・筋の興奮性が抑制され，さらに他髄 節である脛骨神経により支配されたヒラメ筋にも興奮 性の抑制が働いたと考える。

前述したように脛骨神経は, 本研究にて $\mathrm{H}$ 波を導出 したヒラメ筋のみならず, 八ムストリングスと称され る筋群のうち半腱様筋, 半膜様筋, 大腿二頭筋長頭を 支配している神経である。従って, 筆者らの先行研究 での「ジムボールを用いたストレッチング運動が脛骨 神経を介してその被支配筋群の興奮性を抑制する」と いう推察が正しいことが示唆され, 骨盤の傾斜角の増 大は, 被支配筋群である八ムストリングスの興奮性が 抑制されたためであると考えられる。

さらに, 本研究で行ったジムボールを用いたストレッ チング運動は, 直接伸長位にあった背筋群だけでなく, 八ムストリングスなどの下肢筋群の興奮性も抑制する ことができたことから，筋を直接伸長して抑制を図る 従来のストレッチング運動に比べ, 筋が過度に伸長さ れて損傷してしまう可能性が低く, より安全な方法と いえるだろう。

最後に, 本研究を行った際, 対象者からは「腰が楽 になった」,「疲れがとれた」などの感想が聞かれた。ス トレッチングには持続的, 慢性的筋収縮を改善し血管 の圧迫を軽減することによる局所循環の促進の作用が 
あり，このことから疲労回復効果があるといわれてい る ${ }^{8,9)}$ 。疲労を残さない，蓄積しないことは怪我の予防 やパフォーマンスの向上を図る上で非常に重要である ため, 今後の研究課題として, ボールを用いたストレッ チング運動が腰背筋群の疲労に対する効果を検証する。

\section{引用文献}

1) 山際哲夫 : ストレッチングの理論と実際. 医学のあゆみ, 1992, 163(5): 445-449.

2) 原 賢二 : 肉離れのアスレティックリハビリテーション. 医 道の日本，2006, 745: 49-56.

3) 高橋直樹 : 体のバランスを整えながら, 疲労回復を図るボー ルを使ったストレッチング. Training Journal, 2004, 11: 20-23.

4) 江口淳子, 渡邊 進, 小原謙一・他 : ボールを用いた脊柱可 動性増大運動による脊柱彎曲角の変化. 理学療法科学, 2008, 23(1): $17-21$
5) 江口淳子, 小原謙一, 渡邊 進・他：ジムボールを用いた脊 柱可動性運動の効果一運動時間の違いによる検討一. 理学療 法科学, 2008, 23(4): 481-485.

6) 村岡慶裕，正門由久，富田 豊・他：治療的電気刺激による 脳卒中患者の足関節筋群における2シナプス性Ia相反抑制の 変化. リハビリテーション医学, 2000, 37(7): 453-458.

7) 森谷敏夫, 石井千恵 : ボールエクササイズ. 伊丹康人（監 修)。金原出版，東京，1999, pp1-20.

8) 岡田真平, 木村貞治, 武藤芳照 : ストレッチングの生理. 理 学療法, 2000, 17(4): 426-430.

9) 浅井友詞, 鈴木重行, 森本浩之・他 : 体幹に対する徒手療法 ストレッチング。理学療法, 2006, 23(11): 1475-1480.

10) 吉崎邦夫, 遠藤敏裕, 宇都宮雅博 - 他：下腿三頭筋の他動的 ストレッチによる脊髄興奮準位への影響について一反対側 のヒラメ筋H波の変動一. 日本生理人類学会誌，2006, 11(3): 27-30.

11) 弓永久哲, 鈴木俊明: 姿勢変化による上肢脊髄神経機能の興 奮性の変化．総合リ八, 2007, 35(4): 373-378. 